\title{
Current course of measles in adults (a literature review)
}

\author{
Yu. Yu. Riabokon*1,A,E,F, S. O. Bilokobyla ${ }^{1,2, B, D}$, O. V. Riabokon ${ }^{1, B, C, D}$ \\ ${ }^{1}$ Zaporizhzhia State Medical University, Ukraine, ${ }^{2}$ Motor Sich JSC Therapeutic and Health Improving Centre, Zaporizhzhia, Ukraine
}

A - research concept and design; B - collection and/or assembly of data; C - data analysis and interpretation; D - writing the article;

$\mathrm{E}$ - critical revision of the article; $\mathrm{F}$ - final approval of the article

Measles is a highly contagious acute infectious disease of viral etiology. Thanks to the widespread use of measles vaccine in the European Region in the early 2000s, WHO set a goal to achieve measles elimination. An essential feature of measles during the period of elimination was the predominance of cases among adults.

The purpose of the work is to analyze the literature data on the peculiarities of the current course of measles in adults.

According to the WHO, in 2017-2018 in Europe, including Ukraine, there was a significant increase in the number of people with measles. The rise in the incidence of measles in modern conditions is characterized by a change in the genotypes of circulating viruses. The data of modern medical literature show that a significant feature of measles outbreaks in recent years is the predominance of cases among adults, the incidence of measles among medical workers who were vaccinated against measles. The clinical picture of measles in adults remains typical; however, unlike measles in children, it is characterized by a greater incidence of complications.

The development of pneumonia and encephalitis is the most severe and life-threatening. Pneumonia is a frequent complication of measles in adults over 20 years of age, the incidence of which in adults, according to different studies, ranges from 14 to $66 \%$, but the most patients need oxygen therapy. The risk of measles encephalitis occurs during the rash onset and mortality rate depends on the age of patients in this complication: $25 \%$ in adults versus $5 \%$ in children. In adult patients with measles, liver damage is recorded much more often than in children, with the prevalence of cytolytic syndrome, sometimes with the development of jaundice, but is characterized by a benign clinical course. In the literature, there are reports of enteritis and pancreatitis development in patients with measles. Data on the course of measles in pregnant women warrant special attention due to such adverse effects as abortions, premature births, and stillbirths. Measles is a controlled infection, therefore vaccination, including adults, is the main focus in the fight against this disease.

Conclusions. In modern conditions, there is a high incidence of measles in adults, primarily due to the low level of community immunity. The prevalence of adults among measles patients is an important feature of this infection outbreak in recent years. The clinical picture of measles in adults retains typical symptoms, but the course is characterized by a high risk of a wide range of complications, the most severe of which are pneumonia and measles encephalitis. It is possible to achieve success in the fight against measles through the effective vaccination coverage.

\section{Сучасний перебіг кору в дорослих (огляд Аітератури)}

\section{Ю. Ю. Рябоконь, С. О. Білокобила, О. В. Рябоконь}

Кір - висококонтагіозне гостре інсрекційне захворювання вірусної етіології. Завдяки широкому застосуванню вакцинації проти кору в Європейському регіоні на початку 2000-х років ВОО3 поставила за мету елімінацію кору, тобто припинення місцевої циркуляції вірусу. Суттєвою особливістю кору в періоді її елімінації стало переважання дорослих серед тих, хто захворів.

Мета роботи - проаналізувати літературні дані щодо особливостей сучасного перебігу кору в дорослих.

За даними ВОО3, у 2017-2018 роках у країнах Європи, зокрема в Україні, відзначено істотне зростання хворих на кір. Підйом захворюваності на кір у сучасних умовах характеризується зміною генотипів вірусів, які циркулюють. Дані сучасної фахової наукової літератури показують, що суттєвою особливістю спалахів кору в останні роки є переважання серед хворих дорослих, зокрема і медичних працівників, які щеплені проти кору. Клінічна картина кору в дорослих залишається типовою, але, на відміну від кору у дітей, вирізняється більшою частотою розвитку специфічних ускладнень.

Найтяжчим і загрозливим для життя пацієнтів ускладненням є розвиток пневмонії та енцефраліту. Пневмонія - часте ускладнення кору в дорослих, які старші за 20 років, частота розвитку в дорослих, за даними різних дослідників, коливається від 14 до 66 \%, однак більшість пацієнтів потребують проведення оксигенотерапії. Ризик виникнення корового енцефаліту виникає в період появи висипу, при розвитку цього ускладнення летальність має залежність від віку хворого: 25 \% у дорослих проти 5 \% у дітей. У дорослих значно частіше, ніж у дітей, реєструють ураження печінки з превалюванням цитолітичного синдрому, іноді навіть із появою жовтяниці, але характеризується доброякісним перебігом. $€$ також повідомлення про розвиток ентериту, панкреатиту у хворих на кір. Заслуговують на особливу увагу дані щодо перебігу кору у вагітних: зафіксовані такі несприятливі наслідки, як аборти, передчасні пологи та мертвонародження. Кір - керована інсекція, тому головним напрямом боротьби з цією недугою є вакцинація, зокрема й дорослого населення.

Висновки. У сучасних умовах високий рівень захворюваності на кір у дорослих передусім пов'язаний із низьким рівнем популяційного імунітету. Переважання дорослих серед хворих на кір є суттєвою особливістю спалаху цієї інфекції в останні роки. Клінічна картина кору в дорослих зберігає типові ознаки, але перебіг характеризується високим ризиком ускладнень та їхнім широким спектром, найтяжчими є пневмонія та коровий енцефаліт. Досягти успіхів у боротьбі з кором можливо за умови проведення ефективної вакцинації.
Key words: measles, diagnosis, complications.

\section{Zaporozhye} medical journal 2019; 21 (5), 697-701 DOI: 10.14739/2310-1210. 2019.5.179480

*E-mail: RyabokonZSMU@ gmail.com

Киючові слова: кір, діагностика, ускладнення.

Запорізький медичний журнал. - 2019. T. 21, № 5(116). C. 697-701 
Киючевые слова: корь, Аиагностика, осложнения.

Запорожский медицинский журнал. - 2019. -

T. 21, № 5(116). -

C. 697-701

\title{
Современное течение кори у взрослых (обзор митературы)
}

\author{
Ю. Ю. Рябоконь, С. А. Белокобыла, Е. Н. Рябоконь
}

Корь - высококонтагиозное острое инфекционное заболевание вирусной этиологии. Благодаря широкому применению вакцины против кори в Европейском регионе в начале 2000-х годов ВОЗ поставила цель достичь элимининации кори. Существенной особенностью кори в период элиминации стало преобладание взрослых среди заболевших.

Цель работы - проанализировать литературные данные об особенностях современного течения кори у взрослых.

По данным ВО3, в 2017-2018 годах в странах Европы, в том числе и в Украине, отмечено значительное увеличение числа больных корью. Подъем заболеваемости корью в современных условиях характеризуется изменением генотипов циркулирующих вирусов. Данные современной медицинской литературы показывают: существенной особенностью вспышек кори в последние годы является преобладание взрослых среди заболевших, отмечается заболеваемость медицинских работников, которые привиты против кори. Клиническая картина кори у взрослых остается типичной, однако, в отличие от кори у детей, имеет большую частоту развития осложнений. Наиболее тяжелым и угрожающим жизни пациентов осложнением является развитие пневмонии и энцефалита. Пневмония является частым осложнением кори у взрослых старше 20 лет, частота развития которой у взрослых, по данным разных исследований, колеблется от 14 до 66 \%, однако большинство пациентов нуждаются в проведении оксигенотерапии. Риск возникновения коревого энцесралита возникает в период появления сыпи, при развитии данного осложнения летальность зависит от возраста пациентов: 25 \% у взрослых против 5 \% у детей. У взрослых значительно чаще, чем у детей, регистрируют поражение печени с превалированием цитолитического синдрома, иногда с развитием желтухи, однако характеризуется доброкачественным течением. В литературе есть сообщения о развитии энтерита, панкреатита у больных корью. Особого внимания заслуживают данные о течении кори у беременных, при котором зафиксированы такие неблагоприятные последствия, как аборты, преждевременные роды, мертворождения. Корь является управляемой инфекцией, поэтому главным направлением в борьбе с этим заболеванием является вакцинация, в частности, взрослого населения.

Выводы. В современных условиях высокий уровень заболеваемости корью взрослых связан с низким уровнем популяционного иммунитета. Преобладание взрослых среди заболевших корью - существенная особенность вспышки этой инфекции в последние годы. Клиническая картина кори у взрослых сохраняет типичные признаки, однако течение характеризуется высоким риском осложнений и широким их спектром, из которых наиболее тяжелыми являются пневмония и коревой энцефалит. Достичь успехов в борьбе с корью можно при условии проведения эффективной вакцинации.

Measles is a highly contagious infection of viral etiology with a significant risk of developing severe complications. Prior to the mandatory immunization, measles was exclusively a childhood infection and fatal cases of this infection were recorded between 5 million to 8 million in the world annually. The period before the start of the vaccination was characterized by the rise and fall of morbidity, high mortality, a higher proportion of infected children, cyclical changes in the annual dynamics. The development of specific immune prophylaxis of measles and its widespread introduction since 1967 allowed to reduce the incidence by 50 times and mortality rate by 2 times, however, the main determinants of the epidemic process remained $[1,2]$.

Due to the widespread use of measles vaccine in the European region in the early 2000s, the WHO launched a global immunization campaign against measles aiming for a reduction in the local circulation of measles virus eliminating it by 2010 [3]. The elimination period was characterized by a further decrease in measles and variations of the main determinants of the epidemic process. During this period, due to the stable high collective immunity, quantitative changes in the parameters of the epidemic process transformed into qualitative. First of all, measles has been stopped considering as a childhood infection, epidemic centers have become predominant with isolated cases, seasonal factors have almost ceased to influence the epidemic process manifestation in the annual dynamics [2,4].

\section{Aim}

The purpose of the work is to analyze the literature data on the peculiarities of the modern course of measles in adults.
Despite some progress in addressing the issue of the measles elimination in the European region, in particular in Ukraine, the epidemic process remains rather intense, which does not allow the elimination of this infection [5]. Cyclical epidemic and local measles outbreaks suggest the accumulation of susceptible individuals as a consequence of immune prophylaxis defects in the previous years resulting in a decrease in postvaccinal immunity. In recent years, there have been several epidemic outbreaks of measles, in particular, 2005-2006, 2012-2014, 2017-2018 years. Serological studies in Ukraine regarding the definition of the most vulnerable adults among the population made it possible to allocate patients from 16 to 30 years, since only $78.1 \%$ of the examined persons had immunity against measles, which coincided with the high percentage of this age group among patients with measles [6].

Due to the high contagiousness of measles, the level of collective immunity should be very high due to vaccination coverage of $\geq 95 \%$ of the population. This will provide a sufficient level of community immunity to stop the circulation of endemic viruses and prevent their recurrence in case of spreading [5]. Taking into account the official definition of the term "elimination" [7] for verifying the measles elimination in the European Region, WHO is invited to apply the following criteria:

- the absence of endemic measles and rubella cases in all Member States for a period of at least 36 months from the last known case, due to complete interruption of endemic virus transmission;

- the presence of high-quality surveillance system that is sensitive and specific enough to detect, confirm and classify all suspected cases;

- genotyping evidence that supports the interruption of endemic transmission. 
For timely diagnosis of measles, suspicious clinical cases with symptoms that meet the criteria for clinical diagnosis of measles should be considered: fever, maculo-papular rash, cough, drowsiness, conjunctivitis. All suspected cases have to be investigated and classified based on clinical, laboratory and epidemiological data as one of the following [8]:

- laboratory confirmed case of measles: a suspected case which meets the laboratory criteria for measles case confirmation;

- epidemiologically confirmed case of measles: a suspected case which has not been adequately tested by laboratory and which was in contact with a laboratory-confirmed measles case 7-18 days before the onset of rash;

- clinically compatible case of measles: a suspected case which has not been adequately tested by laboratory and has not been epidemiologically linked to a confirmed measles case.

In Ukraine, the system of laboratory confirmation of measles cases was introduced in 2005. Patients with suspected measles were laboratory confirmed in $76.9 \%$ of cases during the epidemic threshold increase in 2006. Epidemiological surveillance of this infection continues with the increase in the measles incidence. Reducing this indicator against the backdrop of $100 \%$ laboratory confirmation of measles cases will be considered effective [9].

According to the WHO, in 2017-2018 in Europe, in particular in Ukraine, there was a significant increase in measles patients. The increase in measles morbidity in modern conditions is characterized by a change in the genotypes of circulating viruses with the predominance of the B3, D8 and D9 genotypes, in contrast to the predominance of the genotype D6 in the early 2000 's $[10,11]$. It should be noted that the genotype B3 is imported into European countries from Africa, located to the south of the Sahara, where its circulation is endemic. Thus, since 2016, in Belgium, France, Italy, Romania, Bulgaria, Portugal, and the United Kingdom along with the circulation of the D8 genotype, a significant number of patients with the B3 genotype of measles virus have been identified $[12,13]$. From 2005-2006, in Europe, there were also sporadic cases of measles due to another imported virus D4 genotype. This genotype is endemic for India, Eastern and Southern Africa, and the Middle East [14]. The effectiveness of post-vaccinal immunity against measles in relation to the level of viruses with different genotypes neutralization by post-vaccine antibody response is still an open question $[4,15]$.

An important feature of the measles outbreaks in recent years is the prevalence among adult patients in the typical clinical picture of measles. In Germany, a percentage of adult patients with measles was $52 \%$ [16], in Italy, 73\% of measles patients were older than 15 years [17], in Belgium, $50 \%$ of patients were over 15 years old [18]. The predominance of adults among patients with measles is noted not only in European countries. Thus, in Sri Lanka, the proportion of patients between 12 and 29 years old was $73.3 \%$ [19], and in Japan, older adults aged 15 to 29 years accounted for $45 \%$ [20] of the total number of patients with measles. In addition, a large number of nosocomial transmission of infection was noted among healthcare workers, especially in those cases when measles patients came to hospitals in the prodromal period of the disease, as well as in cases of severe complications with an atypical course $[12,17]$. Analyzing cases of measles in healthcare workers, it was found that cases of measles also occurred in previously vaccinated individuals [21].

Statistical data on the incidence of measles in different age groups of patients varies in different studies, which is probably due to the analysis of hospitalized patients. At the same time, indications for hospitalization vary around the world. However, almost all studies demonstrate the dependence of complications frequency and their spectrum on patients' age. Children of the first year of life and adults often have a complicated course of the disease $[10,18]$. In Ukraine [10], during the outbreak of measles in 2017-2018, the incidence of severe cases among hospitalized children of the first year of life was $16,7 \%$, at the age of $1-2$ years it was $23.1 \%$, at the age of $2-5$ years $-17.8 \%$, it was the lowest in the age group of 6-11 years, and the highest it was in the age group of children older than 12 years $-21.3 \%$. It should be noted that $82.9 \%$ of complications in children were associated with respiratory system [10].

To date, mechanisms of the complications development in patients with measles are studied. The risk for the development of measles complications correlates with the immunosuppression severity, which develops in patients with measles. However, measles is paradoxically associated with the induction of a strong virus-induced specific immunity which is life-long [22]. Mechanisms of immunosuppression remain insufficiently cleared. A suppression of hemopoiesis, violations of lymphocytes proliferation and immunological memory, destruction of the epithelial barrier, etc. are considered by researchers among key links [22-25].

Pneumonia is one of the frequent and severe complications of measles with the rate of development, according to various authors, varying from 14 to $66 \%[18,26,27]$. The literature suggests that pneumonia is a frequent complication of measles in adults older than 20 years, but the frequency of pneumonia in adult patients with measles varies according to different researchers. At sporadic incidence of measles, the authors recorded a high incidence of cases $-57.1 \%$ (8 out of 14 ) with the development of pneumonia in adults with measles [28]. During the outbreak of measles, Spanish researchers diagnosed pneumonia in $15.3 \%$ of patients [29], Italian authors - in $26 \%$ of patients [30], and French researchers reported the development of pneumonia in $20.6 \%$ of hospitalized adults, the proportion of pneumonia cases increased with age, reaching $28.8 \%$ in adults over 30 years of age [31]. In another French study [32], the development of pneumonia was noted in $31 \%$ of adult patients with measles, $72 \%$ of whom needed oxygen therapy. In Ukraine, in 2017-2018, the analysis of measles complications in the military showed the development of pneumonia in $20 \%$ of cases, while in the cohort study patients with measles had a mild-to-moderate course [14]. All while, the researchers noted that pneumonia was suspected in these patients with measles based on the presence of decreased breath sounds in the lower lung fields in the absence of wheezing, and confirmation of it required not only a chest $X$-ray examination in a number of cases, but also a computer tomography [14]. At the same time, the frequency of pneumonia in children was $4.5 \%$ during the period of measles outbreak in 2017-2018, while the vast majority of these children was over 12 years old [10].

Measles encephalitis is primary and occurs during the period of rash in 1-3 per 1000 infected persons. The 
pathogenetic mechanisms of this complication development have not been fully understood, but onset at the early phase suggested a primary viral invasion of neurological cells, which was confirmed by detection of measles virus RNA in the cerebrospinal fluid followed by chemokine induction and lymphocytic infiltration [33]. The mortality rate reaches 15\% in measles encephalitis and is dependent on patients' age: measles encephalitis-associated mortality is $5 \%$ in children and $25 \%$ in adults. One in four patients endures severe postencephalitic neurological damage [33].

The liver involvement in measles is most common among children older than 15 years of age and adults. In the examination of 140 patients with measles, the development of hepatitis manifested by a cytolytic syndrome without clinical symptoms was observed only in $1.4 \%$ of patients aged 15 and 17 years [10]. In modern scientific literature there is little information about the liver damage in adults with measles, but they all indicate a high incidence of hepatitis in adult measles patients [14,34-36]. Analysis of the course of measles in 65 adults in the 1980s allowed the authors to show the dependence of hepatitis frequency on the disease severity [35]. In the 1990s, Mexican researchers analyzing the course of measles in 201 adults recorded hepatitis in $45 \%$ of patients [36]. In conditions of the current course of measles, the development of hepatitis in adult patients, most authors note much more often the liver damage [14,34]. In the work of French researchers [34], the analysis of measles course in 80 adult patients with a mean age of 30.1 years showed $81 \%$ of hepatitis patients with ALT elevation and in some patients up to a significant level, namely 5 times more than normal in $22.2 \%$ and 10 times more - in $6.2 \%$ of patients. Development of hyperbilirubinemia was noted in $4 \%$ of patients. However, there was no link between the hepatitis incidence and the severity of measles course or the development of bacterial complications in this work. Based on this, the authors considered the development of hepatitis in adult patients with measles as a manifestation of the disease, but not its complication [34]. In the study [14] included examinations of 30 soldiers with measles, a cytolytic syndrome was observed in $60 \%$ of patients, while the severity of measles course was mild-to-moderate.

In the severe course of measles in adults, other gastrointestinal complications are recorded, so, enteritis occurs in $8 \%$ of patients [14]. In the literature, there are a few reports of pancreatic lesion. According to [37], pancreatitis was observed in $1.1 \%$ of patients, and according to [32] - in $2.5 \%$ of adult patients with measles. There is report of Mexican scientists about gastrointestinal complication such as upper gastrointestinal bleeding in $13 \%$ of measles patients [36].

Increasing the incidence of measles among adults leads to a more frequent occurrence of the disease in pregnant women. It is known that measles virus has no teratogenic effect, but measles in pregnant women increases the risk of premature birth and the development of complications [38]. Observations of recent years demonstrated spontaneous abortions or stillbirths in pregnant women with measles [20]. The analysis of the measles course in 4 pregnant women revealed hepatological complication in one case and pulmonary complications and premature births in the other patients [18]. Some authors also reported about complications in pregnant women with measles such as a miscarriage, stillbirth, low birth weight, preterm birth prior to 37 weeks gestation [14].

Etiotropic treatment of measles is not developed. In the modern scientific literature, there are some reports about the efficacy of ribavirin and high doses of vitamin A in the treatment of patients with severe and complicated course of measles $[39,40]$. In a few reports about measles meningoencephalitis, researchers described an empirical use of acyclovir in the treatment of this severe complication, but this did not influence the disease outcome [10].

Measles is a managed infection, so vaccination coverage including the adult population (especially under the age of 30 years) is the most important in this disease control [41-43]. The WHO Strategic Advisory Group on Immunization, after a detailed analysis of scientific data on the biological and technical capabilities of measles elimination, concluded that global measles elimination is biologically justified and cost-effective. The measles should be eliminated by vaccination and integrated surveillance of fever and rash $[41,42]$.

\section{Conclusions}

1. In modern conditions, in the period of measles elimination in the European region, there is a high incidence of measles in adults due to the low level of community immunity and changes in virus strains currently circulating.

2. The prevalence of adults among measles patients is an important feature of this infection outbreak in recent years. The clinical picture of measles in adults retains typical signs, but the course is characterized by a high risk of a wide range of complications, the most severe of which are pneumonia and measles encephalitis.

3. It is possible to achieve success in the fight against measles through the effective vaccination coverage at least $95 \%$ of the population including adults.

Conflicts of interest: authors have no conflict of interest to declare. Конфлікт інтересів: відсутній.

Надійшла Ао редакції / Received: 25.01.2019

Після Аоопрацювання / Revised: 12.02.2019

Прийнято Ао Аруку / Accepted: 26.02.2019

Information about authors:

Riabokon Yu. Yu., MD, PhD, DSc, Professor of the Department of Children Infectious Diseases, Zaporizhzhia State Medical University, Ukraine.

Bilokobyla S. O., MD, Infectious diseases specialist, Motor Sich JSC Therapeutic and Health Improving Centre, Assistant of the Department of Infectious Diseases, Zaporizhzhia State Medical University, Ukraine.

Riabokon O. V., MD, PhD, DSc, Professor, Head of the Department of Infectious Diseases, Zaporizhzhia State Medical University, Ukraine.

Відомості про авторів:

Рябоконь Ю. Ю., А-р меА. наук, професор каф. Аитячих інфекційних хвороб, Запорізький державний медичний університет, Україна.

Білокобила С. О., лікар-інфекціоніст Медико-санітарної частини AT "Мотор Січ», асистент каф. інфекційних хвороб, Запорізький Аержавний медичний університет, Україна.

Рябоконь О. В., А-р меА. наук, професор, зав. каф. інфекційних хвороб, Запорізький Аержавний меАичний університет, Україна. 
Сведения $о 6$ авторах:

Рябоконь Ю. Ю., А-р меА. наук, професор каф. Аетских инфекционных болезней, Запорожский государственный медицинский университет, Украина.

Белокобыла С. А., врач-инфекционист Медико-санитарной части АО "Мотор Сич", ассистент каф. инфекционных болезней, Запорожский государственный медицинский университет, Украина.

Рябоконь Е. В., А-р меА. наук, профессор,

зав. каф. инфекционных болезней, Запорожский

государственный медицинский университет, Украина.

\section{References}

[1] World Health Organization (2011). Measles initiative partners gear up to tackle challenges ahead. Global Immunization News, 9, 4 .

[2] Tsvirkun, O. V., Gerasimova, A. G., Tikhonova, N. T., Turaeva, N. V. \& Pimenova, A. S. (2012). Struktura zabolevshikh kor'yu v period e'liminacii [The Structure of the Measles Cases in the Period of Elimination]. E'pidemiologiya i vakcinoprofilaktika, 2(63), 21-25. [in Russian]

[3] WHO Regional Office for Europe (2003). Strategic plan for measles and congenital rubella infection in the European Region of WHO. Copenhagen. Retrieved from http://www.euro.who.int/_data/assets/ pdf file/0020/79022/E81567.pdf

[4] Volianska, L. A. (2016). Epidemichni realii koru na Ternopilshchyni [Epidemic realities of measles in the Ternopil region]. Aktual'naya infektologiya, 2(11), 98-103. [in Ukrainian].

[5] (2013). Report of the sixty-third session of the WHO Regional Committee for Europe. Cesme Izmir, Turkey, 16-19 September 2013. Copenhagen: WHO Regional Office for Europe. Retrieved from http://www.euro.who. int/_data/assets/pdf_file/0005/234734/Report-of-the-sixty-third-sessionof-the-WHO-Regional-Committee-for-Europe-w-pictures-Eng.pdf?ua=1

[6] Moiseieva, H. V., Zadorozhna, V. I., Demchyshyna, I. V., \& Novyk, L. V. (2010). Monitorinh populiatsiinoho imunitetu proty koru naselennia Ukrainy [Monitoring of population's immunity is against measles of population in Ukraine]. Infektsiini khvoroby, 3, 10-15. [in Ukrainian].

[7] World Health Organisation (2013). Framework for verifying elimination of measles and rubella. Weekly epidemiological record, 88(9), 89-98.

[8] WHO Regional Office for Europe (2013). Surveillance guidelines for measles, rubella and congenital rubella syndrome in the WHO European Region. Update December 2012. Retrieved from http://www.euro. who.int/ data/assets/pdf file/0018/79020/e93035-2013.pdf

[9] Moiseieva, A. (2010). Kontseptsiia eliminatsii koru [The concept of elimination measles]. Sovremennaya pediatriya, 6, 21-24. [in Ukrainian].

[10] Kramarov, S. O., Yevtushenko, V. V., Kovalyukh, I. Yu., Kaminska, T. M., \& Golovach, O. V. (2018). Klinichna kartyna koru v ditei, hospitalizovanykh pid chas spalakhu 2017-2018 rr. [Clinical features of measles in children hospitalized during 2017-2018 outbreak]. Aktualna infektolohiia, 6(5), 240-245. doi: 10.22141/2312-413x.6.5.2018.146773

[11] Rota, P. A., Brown, K., Mankertz, A., Santibanez, S., Shulga, S. Muller, C. P., et al. (2011). Global Distribution of Measles Genotypes and Measles Molecular Epidemiology. The Journal Of Infectious Diseases, 204(suppl_1), S514-S523. doi: 10.1093/infdis/jir118

[12] Grammens, T., Maes, V., Hutse, V., Laisnez, V., Schirvel, C. Trémérie, J., \& Sabbe, M. (2016). Different measles outbreaks in Belgium, January to June 2016 - a challenge for public health. Eurosurveillance, 21(32). doi: 10.2807/1560-7917.es.2016.21.32.30313

[13] George, F., Valente, J., Augusto, G., Silva, A., Pereira, N., Fernandes, T., et al. (2017). Measles outbreak after 12 years without endemic transmission, Portugal, February to May 2017. Eurosurveillance, 22(23). doi: 10.2807/1560-7917.es.2017.22.23.30548

[14] Trykhlib, V. I., Shchur, A. B., Hrushkevych, V. V., Hryshyn, O. S., Pavlovska, M. O., Musiienko, T. I., et al. (2018). Osoblyvosti klinichnykh proiaviv ta perebihu koru [Peculiarities of measles clinical manifestations and course]. Aktualna infektolohiia, 6(3), 141-152. doi: 10.22141/2312413x.6.3.2018.136647 [in Ukrainian].

[15] Kremer, J., Brown, K., Jin, L., Santibanez, S., Shulga, S., Aboudy, Y. 6 et al. (2008). High Genetic Diversity of Measles Virus, World Health Organization European Region, 2005-2006. Emerging Infectious Diseases, 14(1), 107-114. doi: 10.3201/eid1401.070778

[16] Werber, D., Hoffmann, A., Santibanez, S., Mankertz, A., \& Sagebiel, D. (2017). Large measles outbreak introduced by asylum seekers and spread among the insufficiently vaccinated resident population, Berlin, October 2014 to August 2015. Eurosurveillance, 22(34). doi: 10.2807/1560-7917.es.2017.22.34.30599

[17] Lancella, L., Di Camillo, C., Vittucci, A., Boccuzzi, E., Bozzola, E., \& Villani, A. (2017). Measles lessons in an anti-vaccination era: public health is a social duty, not a political option. Italian Journal of Pediatrics, 43(1), 102. doi: 10.1186/s13052-017-0420-6

[18] Grammens, T., Schirvel, C., Leenen, S., Shodu, N., Hutse, V., Mendes da Costa, E., \& Sabbe, M. (2017). Ongoing measles outbreak in Wallonia, Belgium, December 2016 to March 2017: characteristics and challenges. Eurosurveillance, 22(17). doi: 10.2807/1560-7917. es.2017.22.17.30524
[19] Dahanayaka, N. Pahalagamage, S., Ganegama, R., Weerawansa, P., \& Agampodi, S. (2015). The 2013 measles outbreak in Sri Lanka: experience from a rural district and implications for measles elimination goals. Infectious Diseases of Poverty, 4, 51. doi: 10.1186/s40249-015-0084-7

[20] Yasunaga, H., Shi, Y., Takeuchi, M., Horiguchi, H., Hashimoto, H., Matsuda, S., \& Ohe, K. (2010). Measles-related Hospitalizations and Complications in Japan, 2007-2008. Internal Medicine, 49(18), 1965-1970. doi: 10.2169/internalmedicine.49.3843

[21] Amendola, A., Bianchi, S., Frati, E., Ciceri, G., Faccini, M., Senatore, S. et al. (2017). Ongoing large measles outbreak with nosocomial transmission in Milan, northern Italy, March - August 2017. Eurosurveillance, 22(33). doi: 10.2807/1560-7917.es.2017.22.33.30596

[22] Laksono, B. M., de Vries, R. D., McQuaid, S., Duprex, W. P., \& de Swart, R. L. (2016). Measles Virus Host Invasion and Pathogenesis. Viruses, 8(8). doi: 10.3390/v8080210

[23] Ludlow, M., McQuaid, S., Milner, D., de Swart, R., \& Duprex, W. (2014). Pathological consequences of systemic measles virus infection. The Journal of Pathology, 235(2), 253-265. doi: 10.1002/path.4457

[24] de Vries, R., \& de Swart, R. (2014). Measles Immune Suppression: Functional Impairment or Numbers Game? Plos Pathogens, 10(12), e1004482. doi: 10.1371/journal.ppat.1004482

[25] Laksono, B. M., Grosserichter-Wagener, C., de Vries, R. D., Langeveld, S. A. G., Brem, M. D., van Dongen, J. J. M., et al. (2018). In Vitro Measles Virus Infection of Human Lymphocyte Subsets Demonstrates High Susceptibility and Permissiveness of both Naive and Memory B Cells. Journal of Virology, 92(8), e00131-18. doi: 10.1128/jvi.00131-18

[26] Ge, Y. L., Zhai, X. W., Zhu, Y. F., Wang, X. S., Xia, A. M., Li, Y. F., \& Zeng, M. (2017). Measles Outbreak in Pediatric Hematology and Oncology Patients in Shanghai, 2015. Chinese Medical Journal, 130(11), 1320-1326. doi: 10.4103/0366-6999.206358

[27] Xu, Z. W., Chen, Y. P., Yang, M. J., Li, W. C., Liu, Q., \& Lin, J. (2014). The epidemiological and clinical characteristics of measles in Wenzhou, China, 2000-2010. Epidemiology and Infection, 142(1), 20-7. doi: $10.1017 /$ S0950268813000411

[28] Premaratna, R., Luke, N., Perera, H. Gunathilake, M. Amarasena, P. \& Chandrasena, T. (2017). Sporadic cases of adult measles: a research article. BMC Research Notes, 10, 38. doi: 10.1186/s13104-017-2374-6

[29] Monfort, L., Muñoz, D., Trenchs, V., Hernández, S., García, J. J. Aguilar, C. A., et al. (2010). Measles outbreak in Barselona. Clinical and epidemiological characteristics. Enfermedades Infecciosas $Y$ Microbiología Clínica, 28(2), 82-86. doi: 10.1016/j.eimc.2009.05.006

[30] Bassetti, M., Schenone, E., Calzi, A., Camera, M., Valle, L., Ansaldi, F., et al. (2011). Measles outbreak in adults in Italy. Infez Med., 19(1), 16-9.

[31] Antona, D., Lévy-Bruhl, D., Baudon, C., Freymuth, F., Lamy, M., Maine, C., et al. (2013). Measles Elimination Efforts and 2008-2011 Outbreak, France. Emerging Infectious Diseases, 19(3), 357-364. doi: 10.3201/eid1903.121360

[32] Caseris, M., Houhou, N., Longuet, P., Rioux, C., Lepeule, R., Choquet, C., et al. (2014). French 2010-2011 measles outbreak in adults: report from a Parisian teaching hospital. Clinical Microbiology and Infection, 20(4), 0242-0244. doi: 10.1111/1469-0691.12384

[33] Fisher, D., Defres, S. \& Solomon, T. (2015). Measles-induced encephalitis. QJM, 108(3), 177-182. doi: 10.1093/qjmed/hcu113

[34] Dinh, A., Fleuret, V., \& Hanslik, T. (2013). Liver involvement in adults with measles. International Journal of Infectious Diseases, 17(12) e1243-e1244. doi: 10.1016/j.jijid.2013.06.014

[35] Gavish, D., Kleinman, Y., Morag, A., \& Chajek-Shaul, T. (1983) Hepatitis and Jaundice Associated With Measles in Young Adults: An Analysis of 65 Cases. Arch Intern Med., 143(4), 674-677. doi: 10.1001/ archinte.1983.00350040064008

[36] Zhang, Z., Zhao, Y., Yang, L., Lu, C., Meng, Y., Guan, X., et al. (2016). Measles Outbreak among Previously Immunized Adult Healthcare Workers, China, 2015. Canadian Journal Of Infectious Diseases And Medical Microbiology, 2016, 1742530. doi: 10.1155/2016/1742530

[37] Fusilli, G., \& De Mitri, B. (2009). Acute Pancreatitis Associated With the Measles Virus. Pancreas, 38(4), 478-480. doi: 10.1097/ mpa.0b013e31818a3947

[38] Kramariev, S. A. (2008). Kir (klinichna lektsiia) [Measles (clinical lecture)]. Simeina medytsyna, 4, 41-43. [in Ukrainian].

[39] Bichon, A., Aubry, C., Benarous, L., Drouet, H., Zandotti, C., Parola, P., \& Lagier, J. (2017). Case report: Ribavirin and vitamin A in a severe case of measles. Medicine (Baltimore), 96(50), e9154. doi: 10.1097/ md.0000000000009154

[40] Ortac Ersoy, E., Tanriover, M., Ocal, S., Ozisik, L., Inkaya, C., \& Topeli, A. (2015). Severe measles pneumonia in adults with respiratory failure: role of ribavirin and high-dose vitamin $\mathrm{A}$. The Clinical Respiratory Journal, 10(5), 673-675. doi: 10.1111/crj.12269

[41] World Health Organisation (2011). Meeting of the Strategic Advisory Group of Experts on immunization, April 2011 - conclusions and recommendations. Weekly epidemiological record, 86(21), 205-220.

[42] World Health Organisation (2013). Progress in global control and regional elimination of measles, 2000-2011. Weekly epidemiological record, 88(3), 29-36.

[43] Shostakovych-Koretska, L. R., Mavrutenkov, V. V., Cherhinets, A. V., Budaieva, I. V., Yakunina, O. M., \& Chykarenko, Z. A. (2013). Kir (lektsiia, prodovzhennia) [Measles (lecture, continuing)]. Medychni perspektyvy, XVIII (4), 4-15. [in Ukrainian]. 